\title{
HOW NOT TO BE CHIEF JUSTICE: THE APPRENTICESHIP OF WILLIAM H. REHNQUIST
}

\section{LINDA GREENHOUSE ${ }^{\dagger}$}

William H. Rehnquist had an unusually long apprenticeship before he became Chief Justice in 1986. He had already served under two Chief Justices: first under Chief Justice Fred Vinson during his own Supreme Court clerkship for Justice Robert H. Jackson in 1952-1953, and then, of course, during the more than fourteen years that he spent as an Associate Justice on the Burger Court. (You will notice that Rehnquist's Supreme Court biography happens to skip the Warren Court years-not that exposure to Earl Warren would likely have made much difference, but it is worth noting that Chief Justice Warren does not even appear in the index to Rehnquist's book on the Supreme Court, a part-memoir and part-history that he published in 1987. $)^{1}$

The differences between Chief Justice Burger and Chief Justice Rehnquist were manifest. One did not need to be a Court insiderand I do not present myself as one-to observe some of them. For example, during the Burger years, it was regarded as routine that an argued case or two would not be decided by the end of the Term, and instead would be, without explanation, restored to the calendar for reargument during the next Term. The reason, almost invariably, was that the Chief Justice had simply failed to exercise enough leadership to extract from his colleagues something that could pass for an opinion.

Perhaps the most egregious example of this phenomenon was the Court's failure to decide INS v. Chadha, ${ }^{2}$ the legislative veto case, during the 1981 Term. The case was reargued during the 1982 Term and was finally decided on June 23, 1983, by a vote of seven to two, with an opinion for the Court by Chief Justice Burger declaring the legislative veto unconstitutional. The Chadha file was one of the first I looked at when I began my work with the papers of Justice Harry Blackmun at

\footnotetext{
${ }^{\dagger}$ Supreme Court Correspondent, The New York Times.

${ }^{1}$ William H. RehnQuist, The Supreme Court: How It Was, How It Is 338 (1987).

${ }^{2} 462$ U.S. 919 (1983).
} 
the Library of Congress in January 2004. I began with Chadha because, in covering the case as it unfolded, I had been so puzzled by the Court's handling of the case. I was flabbergasted by the real story, which I recount at some length in my book. ${ }^{3}$ To summarize very quickly, Burger froze. His jurisprudential instincts told him that the legislative veto violated the separation of powers, and that was the view expressed at least tentatively by the majority in conference after the argument. ${ }^{4}$ Nonetheless he was terrified by the practical implications of invalidating legislative-veto provisions; some 200 federal statutes contained one-house or two-house legislative veto provisions. ${ }^{5}$ During the entire remainder of the Term after the Chadha argument, Burger never assigned the opinion. Nor was there ever a formal vote to hear reargument in the case. The 1981 Term having ended with no opinion even in circulation, reargument was, however, inevitable. Given the Supreme Court's norms, Burger's failure to assign the opinion was an astonishing failure of leadership.

It is simply impossible to imagine such a scenario on the Rehnquist Court. Chief Justice Rehnquist ran the Court with a firm hand. He did not believe in second-guessing others or-more importantly-himself. I heard him say in conversation more than once that he believed a second or third response to a problem tended to be no more valid than the initial response, and so there was little to be gained by going back to an issue again and again. He believed in simply getting the job done and moving on. Most likely, this was an outlook he developed early in life and brought with him to the Court.

It goes without saying that William Rehnquist and Warren Burger were very different as personalities. Burger was deeply insecure, a trait masked only imperfectly by what often appeared to be pomposity. Rehnquist cared very little about what people thought of him. I cannot say he did not care at all, but I am quite sure he cared less than most people do. His lack of physical grace and his lack of verbal flash contributed to the underestimation, by people who should have

\footnotetext{
${ }^{3}$ See Linda Greenhouse, Becoming Justice Blackmun 154-60 (2005); see also Papers of Harry A. Blackmun, Library of Congress, Manuscript Division, container 352, folders 7-9 [hereinafter Blackmun Papers].

${ }^{4}$ Burger himself abstained from voting at this conference. GREENHOUSE, supra note 3 , at 155 .

${ }^{5}$ See Chadha, 462 U.S. at 944 ("Since 1932, when the first veto provision was enacted into law, 295 congressional veto-type procedures have been inserted in 196 different statues ...." (quoting James Abourezk, The Congressional Veto: A Contemporary Response to Executive Encroachment on Legislative Prerogatives, 52 IND. L.J. 323, 324 (1977))).
} 
known better, of his impressive intellect; I was often surprised at the suggestion that Justice Scalia was the brighter of the two. In any event, Rehnquist's ego was certainly intact. It is impossible to imagine him complaining, as Warren Burger did to his friend Harry Blackmun (before Blackmun became an Associate Justice) in a 1963 letter, about feeling hurt and misunderstood, and about the pain of realizing "how completely I had failed to reveal myself to someone who should have known better what fragile porcelain can reside within a man."

I am not suggesting that Rehnquist developed his approach to being Chief Justice solely in reaction to his perception of Warren Burger's failings. Clearly, Rehnquist's approach reflected his personality, just as Burger's management style reflected his. But neither could Rehnquist plausibly have been untouched by the experience of watching Warren Burger run the Court, or try to. It is my thesis here that Rehnquist took Burger as a negative model, and that his apprenticeship-which, needless to say, has only become an apprenticeship in retrospect-helped him learn how not to be Chief Justice. I think he did observe specific problems with Burger's leadership that he then determined to avoid when his own time came.

Memos from Associate Justice Rehnquist in the Blackmun papers show his frustration, for example, with how Burger ran the conference. Toward the end of the 1974 Term, Rehnquist sent a letter to Chief Justice Burger, with copies to the other Justices:

\section{Dear Chief:}

I had a feeling that at the very close of today's Conference we may have fitted Matthew Arnold's closing lines in "Dover Beach" wherein he refers to those "Swept with confused alarms of struggle and flight / Where ignorant armies clash by night." I therefore take the liberty of stating my understanding that at our Conference Monday morning, immediately after coming off the bench, we are planning to discuss all cases held for opinions scheduled, in Conferences held today or earlier, to come down next week. ${ }^{7}$

The high-toned literary reference here offers only superficial camouflage for what is a very direct and pointed communication. Conferences run by Chief Justice Rehnquist, by contrast, were short and devoid of meandering conversation-to the point where some Justices complained privately that they were devoid of much meaningful con-

\footnotetext{
${ }^{6}$ GReEnHouse, supra note 3, at 39 (quoting Blackmun Papers, supra note 3, container 50 , folder 10 ).

${ }^{7}$ Id. at $153-54$.
} 
versation at all. When I started covering the Court during the Burger years, the last week in September was set aside for what was known as the "long conference," during which the Justices would review the thousand or more petitions for certiorari that had accumulated over the summer recess. The long conference began on the last Monday in September and concluded on the Friday before the first Monday in October, the start of the new Term. During the Rehnquist years, the "long" conference got shorter and shorter until, for most of his tenure, it was finished by lunch on Monday. I would guess that if you mentioned the phrase "long conference" around the Court today, you would get blank stares from all but a few remaining old-timers.

Burger's personal style, as well as his management style, was an irritant to Rehnquist. Blackmun noted a conversation with Rehnquist on January 19, 1981, the day before the inauguration of President Ronald Reagan. "WHR tells me [that the] transition team had asked him to swear in [White House] staff Wed. AM He s[aid] he was on [the] bench the AM but c[oul]d come after 3 PM. They called back to say CJ had preempted! He s[aid] he is furious."

Sometimes, for Rehnquist, Burger's style was the source of hilarity rather than anger. I recently reported an account of a law clerk from the 1980 Term who came upon then-Justice Rehnquist and his law clerks peering through a window that allowed a view from one of the Court's corridors into an interior courtyard. There, Chief Justice Burger was supervising the preparations for a reception. Rehnquist and his law clerks, spying on the scene, were "just spontaneously cracking up at the sight of the chief justice directing the proper placement of the silver," my informant, Robert M. Weisberg, recalled. ${ }^{9}$ (Of course, people are entitled to ask how this apparent disdain for pomposity can be reconciled with Chief Justice Rehnquist's addition of four gold stripes to each sleeve of his judicial robe. I always took this gesture as a flight of fancy rather than a show of pomposity, but the subject remains open to debate.)

After Chief Justice Rehnquist's death in September 2005, Justice Ruth Bader Ginsburg called him "the fairest, most efficient boss I have ever had." Of course, she had not served during the Burger years, so

\footnotetext{
${ }^{8}$ Blackmun Papers, supra note 3, container 1548, folder 4 ("Chronology of Significant Events").

${ }^{9}$ Linda Greenhouse, Court Nominee Well Schooled in Job's Pitfalls, N.Y. TIMES, Sept. 6, 2005, at A1.

${ }^{10}$ Linda Greenhouse, News Was Surprising to Colleagues on Court, N.Y. TIMES, Sept. 5 , 2005, at A19.
} 
whatever other bosses she was using as a standard of comparison did not include Warren Burger. But Rehnquist's fairness in assigning opinions was commonly cited as a contrast to Burger. Rehnquist would count the votes in a straightforward manner and act accordingly; if he was not in the majority, he did not follow the Burger practice, which infuriated the Justices, of withholding or obfuscating his own vote in order to control the assignment function. There are several instances in the Blackmun papers in which Blackmun speculated to himself or to his law clerks after conference that Burger, having voted in the majority and assigned an opinion, would eventually change his vote. ${ }^{11}$

It is worth noting also that while Burger and Rehnquist both had agendas, and both wanted to shift the Court's direction to the right, Burger carried with him a level of anger that was not apparent in Rehnquist. Some of Burger's private comments about the Supreme Court, made to Blackmun during the years before his appointment as Chief Justice, were scathing. "I'm getting so I don't read what these 'phonies' on the Supreme Court write," he wrote in 1961. "The horrible thing is that the Eisenhower appointees are doing most of the damage. This guy Stewart seems to think he must go with the Bastards half the time at least just to prove he's unbiased. God what a weak lot of manpower." 12

It is possible, of course, that we may eventually find a similar letter in the William H. Rehnquist papers, but somehow I would be surprised. ${ }^{13}$ Rehnquist never seemed to take disagreements on the Court personally. Burger, however, saw enemies everywhere and was quick to take offense.

Rehnquist expected others to be aboveboard in their discharge of Court functions. A memo to the law clerks in February 1996 shows his displeasure at learning that law clerks were not honoring the supposedly random assignment of cert petitions to the so-called "cert pool." The pool, comprised of the law clerks from eight chambers (all but the chambers of Justice Stevens), shared the work of going through the petitions and writing advisory memos on their disposition. The practice of randomness was supposed to avoid having ideologically

\footnotetext{
${ }^{11}$ See, e.g., Bob WoOdWARd \& SCOTt ARMSTRong, THE BRETHREN 417-18 (1979)

(describing Justice Brennan's memory of one such instance).

${ }^{12}$ Blackmun Papers, supra note 3, container 50, folder 8.

${ }^{13}$ But see JOAN BISKUPIC, SANDRA DAY O'CONNOR 46 (2005) (quoting a column Rehnquist wrote before being nominated to the Court, in which he criticized the Court's "bleeding heart" criminal jurisprudence).
} 
charged cases fall regularly into the hands of law clerks or chambers with an ideological stake in the outcome. "It has been brought to my attention ... that there are swaps between chambers," Chief Justice Rehnquist wrote. "This sort of trade has the potential for undermining the policy of random assignment of memos, and is, to put it mildly, "not favored." Any deviation from randomness would need his express permission and would have to be "for good cause shown," he said. ${ }^{14}$

Burger made a good deal of the ceremonial function of his office. He gave an annual speech to the American Bar Association, with his arrival and presence at the meeting always causing a stir. Rehnquist announced when he became Chief Justice that he would appear at the ABA meeting only when he had something to say. He attended only twice. He did continue the practice of issuing a year-end report on the state of the judiciary. Often, the subject was judicial independence, threats to the judiciary from the snarled confirmation process, or lack of an adequate pay raise. These bland statements were often heavily coded but easily understood by their intended audience-not the general public but Rehnquist's fellow judges and Congress. It is not clear how much good they did, however.

The image of William Rehnquist in his final months, a frail and desperately sick old man, has undoubtedly erased whatever public memory remained of the young man with the improbable sideburns who was ten years the junior of anyone else on the Court that he joined at the age of forty-seven. Having come from the lively political environment of the Department of Justice, he chafed under the Court's isolation and the rigidity of its social climate. In a memo to Burger just before the start of the 1973 Term, he proposed a few changes that he called "basically housekeeping matters" that he would "greatly appreciate" the Chief Justice putting on the agenda for an upcoming conference. ${ }^{15}$ Among these was a proposal for a "coffee hour" after oral argument. Rehnquist wrote:

I think that the practice which each of us appears to follow at the close of a day of oral argument-plodding back to his own individual salt mine-is bad for morale. While I know there is work to be done, I am wondering if there would be any substantial sentiment in the Conference in favor of opening either the Justices' Dining Room, or one of the Conference Rooms, to all Justices and law clerks who desire it, for a half hour of coffee or tea at 3:00 PM on at least some afternoons following

${ }_{15}^{14}$ Blackmun Papers, supra note 3, container 1374, folder 12.

${ }^{15}$ See GREENHOUSE, supra note 3, at 103 (summarizing Rehnquist's suggestions). 
oral argument. It would give law clerks a chance to get acquainted with the Justices for whom they don't work, and vice versa. ${ }^{16}$

Rehnquist went on to propose a redecoration and expanded use of the Justices' dining room, which

combines, to a degree that might be thought impossible, baronial elegance with dreariness. Might there be some possibility of using the new Chippendale table for those Justices who want to eat with other Justices, but also placing two or three other tables in the same room, in addition to the table in the next room, so that one of us who wanted to have a couple of friends over to lunch could come up and eat in the same dining room, and still not disturb those of the Brethren who wish to eat with one another?

Finally, in this memo, he proposed what he called a "mini-gridiron show":

I would enjoy seeing what each annual crop of law clerks, together with such help from the Justices that they might wish, could do in the way of a gridiron show or other parody or satire on the Court. If we passed this along to the law clerks in the fall, and told them that we would expect a performance some time in the spring, I should think we could have a very enjoyable evening out of it when it occurred. ${ }^{18}$

In a final sentence, Rehnquist added: “Please don't get the impression that I am not working hard in preparation for the first Conference." ${ }^{19}$

Burger's response the following day was not encouraging. "My own attendance would be brief or rare, or both" at any coffee hour, he wrote. Burger was "not in the mood to see law clerks generally," due to "leaks" that had occurred the previous Term. He was not, however, more specific about what those leaks were. As for the dining room, "You should have seen it in 1969," wrote Burger, when it resembled a local funeral parlor. And as for a law clerks' show, Burger wrote, "I'll try to keep an open mind. Something like this was tried at my old court. Just once!" ${ }^{20}$ (Rehnquist, as Associate Justice, once in my hearing tried to recruit the Supreme Court press corps to put on a satirical show for the Justices, but somehow that idea never came to fruition.)

${ }^{16}$ Letter from Justice William Rehnquist to Chief Justice Warren Burger (Sept. 24, 1973), in Blackmun Papers, supra note 3, container 170, folder 3.

${ }^{17} \mathrm{Id}$.

${ }^{18} I d$.

${ }^{19} I d$.

${ }^{20}$ Letter from Chief Justice Warren Burger to Justice William Rehnquist (Sept. 25, 1973), in Blackmun Papers, supra note 3, container 170, folder 3. 
I do not mean to suggest that under Chief Justice Rehnquist, the Supreme Court was transformed into a warm and cozy clubhouse. It remained a very businesslike place, even as the business at hand, perhaps not entirely coincidentally, diminished substantially. With the number of opinions written on the merits each Term around 70, the Rehnquist Court cut its workload in half. Never having been invited to attend the annual law clerks' show that is now a feature of the closing days of the Term, I cannot say whether all, or any, of the time thus freed up has been put to good use. Having in recent years attended the Court's Christmas party, from which Chief Justice Burger excluded the press, I can report that Chief Justice Rehnquist greatly enjoyed his role there as master of ceremonies and leader of the singalong. His absence last December was a sad way to end the year.

So now we have a new Chief Justice who knew the Burger Court as a law clerk to William Rehnquist twenty-five years ago and knew the Rehnquist Court as a practicing member of the Supreme Court bar. On his first day on the bench last month, Chief Justice Roberts appeared without any gold stripes on his sleeves. ${ }^{21}$ Maybe he felt he had not earned them yet. Certainly he has learned from both of his predecessors. What lessons he took away from them, we shall soon see.

${ }^{21}$ See Linda Greenhouse, A Ceremonial Start to the Session as the Supreme Court Welcomes a New Chief Justice, N.Y. TIMES, Oct. 4, 2005, at A25 (describing the scene the day Chief Justice Roberts' tenure on the Court began and noting that the new Chief Justice's "judicial robe was unadorned, lacking the four gold stripes that ... [Rehnquist] had added to each sleeve to brighten up the basic black"). 